Short communication

UDC $94(3)$

DOI 10.18413/2312-3044-2020-7-2-169-175

\title{
Church in the Late Roman Empire: the Current State of Research
}

\author{
M. V. Gratsianskiy \\ Moscow State University \\ Lomonosovskii pr. 27/4, Moscow, 119991, Russia \\ E-mail: gratsianskiy@mail.ru
}

Copyright: (C) 2020 Gratsianskiy, M. V. This is an open-access publication distributed under the terms of the Creative Commons Attribution License, which permits unrestricted use, distribution, and reproduction in any medium, provided the original authors and source, the Tractus Aevorum journal, are credited.

One of the most representative institutions of late antiquity and, according to many scholars, one of the most important signs by which late antiquity is currently distinguished in a separate historical period, which is subject to special study, is the church. After the turbulent events of the 3rd century, currently considered as the threshold of the onset of late antiquity, the subsequent era of Diocletian-Constantine (284-337) was marked by a series of transformations that radically changed both the internal structure of the Roman state and, in many ways, Roman society itself. The last and most widespread persecution of Christians, undertaken at the end of the reign of Diocletian and continued under his closest successors, the tetrarchs, ended in the years marked by the eminence and establishment of the emperor Constantine. The recognition of Christianity as the "permitted religion" following the publication of the Edict of Milan of 313 served as the beginning of another period of its active dissemination, which, on the whole, ended by the end of the $4^{\text {th }}$ century with the actual affirmation of Christianity not only as the dominant but even as the state religion of the Roman Empire.

Relations between the Roman state and the Church were an invariable subject of research long before the recognition of late antiquity as an independent historical period in the 1980-90s. The greatest contribution to his study at an early stage in the development of the critical-historical method in the second half of the $19^{\text {th }}$ century. It was made by German Protestant scholars, who saw the state influence on the development of the Church and the role of the emperor in it as an important argument in polemics with Catholics, who openly diminished or even denied the possibility of the lawful influence of the state on the Church in general and

ISSN 2312-3044 | http://belsu-tractus-aevorum.ru 
on church and administrative structures in particular. At the same time, it should be recognized that at that stage the study of both church-state and purely church issues was at an embryonic level due to the relatively low availability of the entire spectrum of sources and due to the fact that their full critical publication was just beginning at that time.

However, at that time, the general research, in particular the works by J. Bury, Yu.A. Kulakovski, E. Stein, A.H.M. Jones et al., which arose at a time when the concept of late antiquity had not yet been shaped and came out as part of a study of the history of the "late Roman Empire" or "early Byzantium", were of no less, if not more, significance for the study of church subjects of the period of late antiquity. Meanwhile, the formation of a special direction of studies of late antiquity helped scientists concentrate on the features of the studied period and abandon the need to consider it only as a transitional stage between the more "significant" epochs of ancient antiquity and the Middle Ages. With regard to the study of the history of the Church, this led to the fact that the indicated period began to be considered in fact as "normative" and having fundamental significance for all subsequent eras of church-historical development, not excluding the current one.

So, the history of the Church as an institution of late antiquity has become an integral part of historical research, and a previously rare phenomenon has often been observed when historical information contained in sources of a church character or church origin is naturally applied to the study of any aspects of the history of the Roman Empire, and above all Roman society. This process should be perceived as completely natural and inevitable in view of the fact that sources of church origin or in any way relating to the Christian religion and the Church represent perhaps the largest part of the surviving sources of the period of late antiquity in general both in number of the sources and in their volume,.

Church-historical studies devoted to this period, of course, could not have developed in a modern form without the colossal publication work done by the historical science of the last one and a half centuries. Numerous published series, such as Monumenta Germaniae Historica, Sources Chrétiennes, Corpus Christianorum, Corpus Fontium Historiae Byzantinae, Patrologia Orientalis, Corpus Scriptorum Christianorum Orientalium, as well as many others, not to mention smaller-scale series and extra-series publications, which were inaccessible or inaccessible to previous generations of researchers, have been made available to modern scholars as comfortable and well-made modern editions of a huge number of sources on the history of the Christian religion and the Church. It is on this excellent base from the beginning of the 1990s that the rapid growth of the study of late antiquity is observed, which continues to this day.

Perhaps the main achievement of the science of late antiquity is, as has already been said, the emphasis on the study of Roman society mainly in the $4^{\text {th }}-7^{\text {th }}$ centuries in all possible aspects. The fact that the source dominates and the relatively easy verifiability of the source data and the 
conclusions of each particular researcher have led to the high accuracy in handling the source. As a result, in modern conditions it turns out to be difficult to maintain hypotheses or ideological principles to the detriment of the data contained in the sources. Thus, the science of late antiquity was in an amazing position: with a very large abundance of research, it is extremely difficult to distinguish certain "ideological" or "conceptual" directions among them. Any attempt to "cut corners" in the study and go on to generalizations seems to be problematic at present due to the abundance of available facts and the large number of private papers and studies that need to be taken into account and evaluated. And this is not to mention the comparative abundance of sources, the completeness of involvement and the correct reading of which becomes the key to a successful study and the soundness of the conclusions made on its basis.

In relation to the history of the Church, this situation is expressed in the revision of many church-historical concepts and approaches based in the past, primarily on the existing confessional differences. Apparently, attempts at present to build confessional schemes based on selective reading and application of information from church-historical sources of various genres are doomed to failure in the short term. On the other hand, the unprecedented accessibility of the best source material of late antiquity circulation for the entire period of the existence of historical science makes it possible to create the most reasonable picture of all aspects of the history of the Church, excluding the use of "indiscriminate" ideologies sometimes having over a hundred years behind them.

Thus, at the present stage, it is quite possible and permissible to clarify or even revise both scientific and church-political concepts dealing with or appealing to the church-historical reality of the first millennium of the Christian era. First of all, this concerns issues of the canonical tradition, inter-church and church-state relations, the place and role of the leading bishops, councils, etc.

The most promising direction in the study of the history of the Church of the late antique period is its consideration as a specific public institution of the Roman Empire. The political and religious realities of the Roman Empire belonged to the conduct of society (populus), since, according to Roman views, power and religion were purely public institutions and implied the participation of full members of society in their functioning. Thus, the observations of numerous modern scholars showing how the institution of church clergy arises from the conditions and needs of urban communities, organizing, through collective efforts, parish structures that control the clergy themselves and directly affect the bishop's election, are very important. The specificity of relations within the episcopal corps also seems extremely curious and multifaceted, where internal relations are determined by the complex interweaving of dogmatic, political and even economic interests, which, with the introduction of a geographical dimension here, led to the creation of the concept of "geo-ecclesiology". This 
concept, which is fruitful in nature, although it has not yet received sufficient justification even in the reasoning of the researcher who proposed the indicated term, seems to have a serious potential for development and elaboration.

Also, very important are the achievements of modern science about late antiquity in the study of the Church in various geographical areas of its existence, represented by the regions of the Roman Empire. Modern approaches, the availability of sources, and research already done help to put the history of each local Church in its exact geographical context and, more importantly, take the relevant regional specificity into account, which determines a number of parameters of the existence of each particular church (if we are talking about the so-called future "Pentarchy", the five "great thrones") or a set of regional churches that are not united by a recognized and canonically fixed center. In this case, for the most part, we can talk about the territories of the Western Roman Empire, united during the $4^{\text {th }}-5^{\text {th }}$ centuries into the prefecture of Gallium (praefectura Galliarum) and Italy, including Illyric. Thus, the situation in the West, i.e. in the territories belonging to the Western Roman Empire between 395-476, seems extremely "motley" in the sphere of inter-church relations because along with the centers of church-political "crystallization", such as Rome or Carthage, there were also prefecture centers of great church-administrative importance, such as Milan and Arles, while the vast expanses of Spain, a large part of Gaul, Italy and Illyric did not have unambiguously recognized centers for generally binding church-administrative decisions, often even at the provincial level. However, in the East, where the church-administrative situation was usually perceived by researchers as more ordered, there remains a lot of room for studying regional church-political specifics, determined by the conditions of local society, interests of regional elites, structure of state-administrative division, relations with neighboring regions and the central authorities of the Eastern Empire and, not least, the economic situation.

Certainly promising is the study of the Council as an important institution for the functioning of the Church starting from the period of late antiquity. At present, the study of church councils, as well as other aspects of the history of late antiquity, is flourishing, caused primarily by the fact that the critical edition or reprint of the entire collection of council acts of the late antiquity and early medieval period is actually complete and extensive work has already been done on their analysis. conciliar acts have been thoroughly analyzed from the point of view of intra-church relations, although the church-state and social aspects of the conciliar movement, especially with reference to sources on Ecumenical councils and councils of "great thrones" obviously need further elaboration. The potential of the study of councils in order to identify the features of their legal, administrative and social status and development of the Roman Empire in the $4^{\text {th }}-8^{\text {th }}$ centuries is still huge. To study individual regions of the Roman 
Empire, including beyond the chronological limits of the existence of Roman state power in them, as well as the study of local church councils, often provides unique information on all aspects of local societies, and in the case of territories torn away from the Roman Empire it allows you to additionally judge the processes of continuity or discontinuity in the development of regions in comparison with the Roman period.

Conciliar acts are also extremely important for studying the reception of Roman law in church life and in the formation of the so-called canon law, although it should be recognized that during the first millennium the latter was not perceived as a separate legal system (with possible reservations regarding the Latin West). Due to the codification of Roman law, the latter is largely under the jurisdiction of historians of late antiquity, and crossexamination of the processes of creating a late antique legal system by historian-lawyers and canonist historians is very fruitful at present. Examples of fruitful interaction between them are already available in the Western research.

So, as already noted, church-historical works of various genres are often unique sources for studying the regions of the Roman Empire. Moreover, in a number of cases they shed light on regions that, until the period of late antiquity, are sometimes very poorly represented in historical narratives or documents. Thus, in particular, Roman Gaul actually comes out of the shadow thanks to late-antique and, not least, church historical sources. For the previous centuries, before the adoption of Christianity as an allowed religion, our sources of Gaul are rather scarce and fragmented. However, starting from the $4^{\text {th }}$ century $\mathrm{AD}$ and later through the late antiquity to the Middle Ages (whatever the chronological separation between them), they become relatively numerous and very diverse in genre, but to a large extent or even mainly are the examples church writing.

However, this applies not only to the poor sources in the preceding era of the West, but also to the traditionally rich East. Most productive in general, and as a result, abundant in terms of written sources, is the east of the Roman Empire, and especially the area called the "East Diocese" (dioecesis Orientis) with its center in Antioch. Not to mention the fact that this region is the cradle of Christianity, it is also, thanks to the fact that such figures of Christianity as Sextus Julius Africanus, Origen, Eusebius of Caesarea and many others lived there, is the cradle of a number of church historical genres, such as everyday literature, church chronography, church history, and even church archeology. Apparently, the influence of this region on the formation of the Christian written (but by no means only written) tradition should be recognized as decisive. The leading role in the formation of church tradition in this region, along with Egypt, undoubtedly continued until the Arab conquests.

The intellectual environment of the East was naturally formed not only due to the Christian factor, but largely due to the fact that its urban centers were centers of traditional ancient science, rhetoric and philosophy, 
which received another boost in the $5^{\text {th }}-6^{\text {th }}$ centuries. Christian thought was in a fruitful dialogue with the philosophical thought of late paganism, represented primarily by neo-Platonic synthesis. It is often extremely difficult to separate Christian thinkers from Neoplatonic ones since the latter during that period were mostly Christians. Thus, the period of classical patristics turns out to be a product of the Late Antique period, marked, among other things, by the flourishing of traditional ancient science. The intellectual environment of the Late Antiquity is thus becoming an object of special study, and it should be noted that research on this subject is also currently in rapid bloom both abroad and in our country. The study of the intellectual environment of late antiquity at the present time, in addition to studying the topical issues of philosophy and theology, is also the subject of sociological and economic studies. Also promising are studies of the relationship between the intellectuals of late antiquity and the authorities of the Roman Empire, their involvement in urban, provincial and imperial government, as well as the involvement of philosophical schools and individual intellectuals in the civil, religious, and political processes in the Roman Empire.

In connection with the study of the peculiarities of the philosophical development of the regions of the Roman Empire, mainly of the East, there is also a study of the particularities of the development of theology. Traditional confronting between the Alexandrian and Antiochian "theological schools" was replaced by a very nuanced picture of the formation, development, struggle, spread and extinction of certain theological trends. It all took place against the background of a fierce struggle between church and political circles of various Roman regions, clearly defending their regional interests in addition to the theological truth. The theological and church-political struggle, thus, is closely intertwined with the internal politics of the western and eastern parts of the Roman Empire, as well as with the opposition of both of them to each other, especially in the period between 395-476, when the political confrontation was obviously conducted in all areas, not excluding the church, and the change in political course was almost always accompanied by a change in theological orientation, fixed in changes in dogmatic definitions adopted by the cathedrals and enshrined in imperial legislation.

As a result, further clarification of the issue of the role of the emperor and imperial power in the Roman Empire is of great importance for characterizing the features of the Late Antique period. This question can in no way be called new or unexplored, since its study has been going on for a very long time, beginning long before the term "late antiquity" was introduced into a wide circulation. However, modern possibilities open up new prospects for its study in the framework of late antiquity studies. The issue of the limits of imperial power in church affairs and the related question of the integration of the Church into the legal system of the Roman Empire, which reached its maximum degree in the era of Justinian the Great 
(527-565), still remains fruitful in terms of studying the history of the Church.

Considering all above said, a discussion of these and other issues, which previously belonged entirely to church-historical subjects and were mainly the destiny of Church historians, now seems impossible without the widespread involvement of data and approaches that relate to other, completely "secular" spheres of historical knowledge. In the modern Western research community dealing with the history of late antiquity, the institutional framework between church and secular history has completely collapsed, and research is carried out mainly in a complex manner. Similar trends are gaining strength in Russia, although it is regrettable that we have to admit that the "late antique revolution" in world historiography still remains largely unnoticed in Russian science, and its consequences not rated. The potential of the concept of "late antiquity" for the possible revisal of historical concepts, in particular relating to the theory of the change of historical eras, also remains untapped. As an example, one of the particular results of a study of late antiquity is a convincing revision of the date of the fall of the Western Roman Empire as the turn of antiquity and the Middle Ages. Now it is no longer possible to unconditionally adhere to this date as marking some fateful event and thereby ignore what happened in Roman society both in the territories where Roman state power was preserved and in the territories where it was lost after this date. The approach to the history of the $4^{\text {th }}-10^{\text {th }}$ centuries from the point of view of the specifics of the Late Antique processes provides great prospects for studying the entire period. Apparently, the period is even larger than the traditional view of this period as the early Middle Ages.

Translated from Russian by Alexander M. Amatov

Received March 17, 2020

Published December 14, 2020 